EDITORIAL

\title{
A revista Ciência da Informação ante o novo contexto da comunicação científica
}

A revista Ciência da Informação, em um esforço de acompanhar e refletir sobre as mudanças conjunturais inerentes à sociedade do conhecimento, lança, a partir deste número, sua nova logomarca, refletindo a quebra de paradigmas necessários a instituições deste novo contexto.

Apresenta, em seu fascículo, temas emergentes que representam a preocupação estratégica do Instituto, isto é, a busca intermitente do conhecimento nas questões ligadas à informação, e a solução, por meio desta, de problemas do cotidiano, com vistas a disseminar experiências e estudos à sociedade.

Nessa linha, ao limiar da terceira revolução do livro, com a quebra de mais um paradigma quanto ao formato, suporte e gravação para a comunicação de textos, surge o e-book, o livro eletrônico, a textualização eletrônica, o periódico eletrônico, a intermediação entre o hipertexto, a tela do computador e o leitor.

Em meio a essas mudanças, que nos apontam a nova comunicação científica eletrônica, o " periódico, apesar dos seus mais de trezentos anos de existência, ainda mantém sua estrutura básica e continua sendo o canal mais relevante para a comunidade científica, pois nele são disseminadas as pesquisas mais recentes de uma área, sob a forma de artigos.". (Pinheiro, L. IBICT. GT15- Serviço de informação e publicações para especialistas em ICT. Relatório final. 2001, p.3).

Finalmente, espera-se que a leitura dos artigos venha subsidiar a reflexão sobre as mudanças globais e as necessidades emergentes de uma sociedade em que tudo está sendo reavaliado.

Almiro Blumenschein Diretor do IBICT 